УДК 349.2

DOI: 10.31453/kdu.ru.978-5-7913-1143-6-2020-30-36

Балтутите Иоланта Видмантовна

Baltutite Iolanta Vidmantovna кандидат юридических наук, доцент, доцент кафедры гражданского и международного частного права (базовая кафедра ЮНЦ РАН) $\mathrm{PhD}$ in Law, Associate Professor, Department of Civil and Private International Law (the Basic Department of the UNC RAS) Волгоградский государственный университет

Volgograd State University

\title{
ОСОБЕННОСТИ РАЗВИТИЯ ТРУДОВЫХ ОТНОШЕНИЙ В ПАРАДИГМЕ ИНДУСТРИИ 4.01
}

\section{FEATURES OF THE DEVELOPMENT OF LABOR RELATIONS IN THE PARADIGM OF INDUSTRY 4.0}

Аннотация: В статье рассмотрены вопросы трансформации рынка труда и трудовых отношений под влиянием четвертой промышленной революции. Изучены проблемы, с которыми столкнулся рынок труда в условиях цифровизации экономики в период пандемии короновирусной инфекции. Установлена необходимость формирования концепции благоприятной, адаптивной правовой среды, необходимой для реализации национальной программы «Цифровая экономика РФ». Выявлены основные недостатки действующего трудового законодательства, пробелы гражданско-правового механизма защиты прав и законных интересов субъектов трудовых правоотношений, основанные на технологиях индустрии 4.0, а также, основанных на технологиях индустрии 4.0.

Abstract: The article deals with the transformation of the labor market and labor relations under the influence of the fourth industrial revolution. The problems faced by the labor market in the context of the digitalization of the economy during the coronavirus pandemic were studied. The necessity of forming the concept of a favorable, adaptive legal environment necessary for the implementation of the national program "Digital Economy of the Russian Federation" is established. The main shortcomings of the current labor legislation, gaps in the civil law mechanism for protecting the rights and legitimate interests of subjects of labor legal relations, based on industry 4.0 technologies, as well as based on industry 4.0 technologies, have been identified.

\footnotetext{
${ }^{1}$ Исследование выполнено за счет гранта Российского научного фонда (проект № 20-18-00314).
} 
Ключевые слова: цифровая экономика, цифровые технологии, трудовые отношения, пандемия, электронный документооборот.

Key words: digital economy, digital technologies, labor relations, pandemic, electronic document management.

В современных условиях развития экономики наблюдается расширение применения цифровых технологий во всех видах экономической деятельности. В настоящее время цифровые технологии в трудовых отношениях и рынок труда в целях формирования продуктивной занятости опираются на требования Национальной программы «Цифровая экономика Российской Федерации» [4], направленной на достижение цели, определенной Указом Президента РФ от 7 мая 2018 г. № 204 «О национальных целях и стратегических задачах развития Российской Федерации на период до 2024 года» в части решения задач и достижения стратегических целей по направлению «Цифровая экономика» [5]. Необходимо формирование концепции благоприятной, адаптивной правовой среды, необходимой для реализации данной национальной программы.

Рынок труда является наиболее чувствительным индикатором изменений, происходящих в рыночной экономике, и подвергается очень существенному изменению под влиянием процессов цифровизации.

Трудовое право ранее уже обращалось к цифровому документообороту. Еще в 2013 г. в Трудовом кодексе РФ (далее - ТК РФ) появилась глава 49.1 о дистанционном труде, которая разрешает использовать электронную цифровую подпись, если сотрудники работают удаленно.

В настоящее время разработан комплекс предложений по внесению поправок в действующее трудовое законодательство об использовании цифровых технологий при трудоустройстве. В список вошли платформенные решения для развития системы занятости, внедрение цифрового оборота документов о трудовой деятельности, а также поправки в законы, призванные «упростить регулирование режимов удаленной занятости».

Практика, при которой работодатель позволяет работнику периодически работать из дома применяется давно, но она не была оформлена законодательно. 
При этом внести изменения в трудовое законодательство и предусмотреть временную удаленную занятость законодатели не спешили. Вероятно, были опасения того, что стороны могут злоупотребить своими правами в условиях большей гибкости и меньшей формализованности трудовых отношений,

Пандемия скорректировала ситуацию: необходимость изменений трудовых норм стала очевидна, а Министерству труда даже пришлось выпускать памятку о переводе на удаленную работу, чтобы дать работодателям хоть какойто инструмент взаимодействия с работниками.

Правительство России предлагает после пандемии в сфере поддержки занятости населения предлагает закрепить дистанционные формы занятости, внедрить цифровые технологии в документооборот, а также меры поддержки безработных граждан. Общенациональный план восстановления экономики [3], подготовленный Правительством РФ, является продолжением пакета антикризисных мер, направленных на поддержку занятости и доходов населения, а также восстановление экономической активности в целом.

План предполагает цифровизацию трудовых отношений и оказания государственных услуг по содействию занятости: перевод госуслуг гражданам и предпринимателям в электронный вид с использованием ресурса "Работа в России"; повышение эффективности служб занятости населения за счет взаимодействия граждан и работодателей в электронном виде; переход на электронный кадровый документооборот в 2021 году для всех работодателей.

В рамках плана предлагается развитие программ дистанционного обучения; внедрение взаимосвязанных цифровых платформ по образованию, повышению квалификации, поддержке занятости; усиление роли коллективных договоров и трудовых договоров при предоставлении гарантий и компенсаций работникам, совмещающим работу с получением высшего образования, среднего профессионального образования; предоставление выбора по соглашению сторон трудового договора устанавливать испытательный срок, заключать срочный (на срок до 1 года) трудовой договор или принимать выпускника на стажировку выпускников образовательных учреждений среднего 
профессионального и высшего образования, регулирование условий перехода срочного договора в бессрочный договор.

Действующие нормы ТК РФ на фоне пандемии коронавируса устарели, при этом права дистанционно работающих сотрудников недостаточно защищены.

Нами выявлены основные недостатки действующего трудового законодательства, основанные на технологиях индустрии 4.0:

- не урегулированы вопросы оформления на работу и увольнения при дистанционной работе;

- не установлена продолжительность рабочего времени при удаленной работе и, соответственно, размер заработной платы работнику в связи с переводом на удаленную работу;

- не регламентировано предоставление отпуска во время удаленной работы;

- не приняты во внимание возможности технического оснащения для организации дистанционной работы гражданами;

- не урегулированы вопросы представительства и защиты прав работников и работодателей в онлайн-формате.

Пандемия ускорила процессы цифровизации в трудовых отношениях. Ярким свидетельством недостаточности нормативного регулирования стало появление ряда законопроектов, посвященных гражданско-правовому регулированию трудовых отношений: законопроект № 966659-7 «О внесении изменений в статью 57 Трудового кодекса Российской Федерации» [1], разработанный Московской городской Думой; законопроект № 973264-7 «О внесении изменений в Трудовой кодекс Российской Федерации в части регулирования дистанционной и удаленной работы», разработанный депутатами Государственной Думы РФ [2].

Первый документ менее проработан и предлагает поменять ст. 57 ТК РФ "Содержание трудового договора". В проекте предлагалось указывать в 
документе график удаленной работы и способ коммуникации с работником. Многие вопросы оставались не решенными.

Второй законопроект предлагает перевести весь документооборот между руководством и сотрудниками — вплоть до листка нетрудоспособности, в цифровой формат, и только в отдельных случаях - например, при предоставлении декретного отпуска, высылать документы заказными письмами. По мнению авторов поправок, нормы цифрового документооборота необходимо закрепить в трудовом договоре о дистанционной работе, который также предлагается заключать онлайн.

Трудовой договор о дистанционной работе также должен включать пункт о том, какой техникой пользуется удаленный работник, собственной или работодателя. В некоторых случаях со стороны компании может быть предусмотрена компенсация за использование личного оборудования сотрудника.

Трудовое законодательство должно содержать положения о приравненности электронного трудового договора к письменной форме.

Законопроект определит основные характеристики дистанционной работы — выполнение обязанностей вне офиса, взаимодействие с работодателем через интернет, время работы и отдыха сотрудника. Работник сможет самостоятельно устанавливать себе график - в случае, если иное не предусмотрено трудовым договором.

Компания и сотрудник смогут согласовать временной диапазон взаимодействий, когда работодатель может звонить или писать в мессенджерах. Работник получит право не реагировать на обращения вне графика. Поправки также предусматривают введение норм сверхурочной удаленной работы например, при чрезвычайной ситуации, но только с личного согласия сотрудника и с дополнительной оплатой.

Важным является то, что поправки подразумевают ограничить продолжительность рабочего дня на дистанционной работе восемью часами как и трудовое время в обычном офисе. 
В документе пока не раскрыта тема охраны труда. Кроме того, по нашему мнению, недостаточно регламентирован вопрос предоставления оборудования и компенсации расходов, понесенных удаленными работниками.

Ускоренная цифровизация трудового законодательства станет одним из факторов общенационального плана действий по восстановлению экономики и борьбы с безработицей. Цифровизация трудовой деятельности также является частью национальной программы «Цифровая экономика», которая предусматривает переход на электронные трудовые книжки, эксперимент с электронным документооборотом и другие проекты.

Цель изменений в ТК РФ - повышение гибкости занятости, применение информационно-коммуникационных технологий в трудовых отношениях, защита прав работников. Для этого, прежде всего, предлагается усовершенствовать нормы по дистанционной работе и урегулировать отношения временной дистанционной (удаленной) занятости.

В сфере поддержки занятости населения необходимо закрепить новые (дистанционные) формы занятости, внедрить цифровые технологии в документооборот в рамках трудовых отношений, поддерживать выпускников профессиональных образовательных организаций, а также работников, получающих образование.

Отсутствие в трудовом законодательстве норм, управомочивающих субъектов трудового права на электронное взаимодействие, создает в их отношении ситуацию правовой неопределенности.

«Эпоха коронавируса» ускорила цифровизацию системы социальнотрудовых отношений, что само по себе требует нового «цифрового» качества предоставления государственных услуг в этой сфере. Стали востребованы представительство и защита прав работников и работодателей в онлайн-формате.

Трудовые вопросы затрагивают как насущные интересы граждан, так и проблемы экономики страны, особенно пострадавшей в период эпидемии. Целесообразно, на наш взгляд, выработать единый и защищенный сервис для всей судебной системы России с возможностью доступа к нему граждан из 
конкретных домохозяйств, таким сервисом может быть видеосвязь посредством интернет-портала государственных услуг.

\section{Acknowledgement}

The work was supported by Russian Science Foundation (project №20-18-00314).

\section{Библиографический список:}

1. Законопроект № 966659-7 «О внесении изменений в статью 57 Трудового кодекса Российской Федерации» [Электронный ресурс] // Режим доступа: https://sozd.duma.gov.ru/bill/966659-7 (дата обращения: 31.07.2020).

2. Законопроект № 973264-7 «О внесении изменений в Трудовой кодекс Российской Федерации в части регулирования дистанционной и удаленной работы», разработанный депутатами Государственной Думы РФ [Электронный pecypc] // Режим доступа: https://sozd.duma.gov.ru/bill/973264-7 (дата обращения: 31.07.2020).

3. Общенациональный план восстановления экономики является продолжением антикризисных мер Правительства [Электронный ресурс] // Режим доступа: https://www.economy.gov.ru/material/news/ekonomika_bez_virusa/minekonomrazvi tiya_rf_obshchenacionalnyy_plan_vosstanovleniya_ekonomiki_yavlyaetsya_prodolz heniem_antikrizisnyh_mer_pravitelstva.html (дата обращения: 29.07.2020).

4. Паспорт национального проекта «Национальная программа «Цифровая экономика Российской Федерации», утв. президиумом Совета при Президенте РФ по стратегическому развитию и национальным проектам, протокол от 04.06.2019 № 7 [Электронный ресурс] // Режим доступа: http://www.consultant.ru/document/cons_doc_LAW_328854/ (дата обращения: 31.07.2020).

5. Указ Президента РФ от 7 мая 2018 г. № 204 «О национальных целях и стратегических задачах развития Российской Федерации на период до 2024 года» // "Собрание законодательства РФ", 14.05.2018, N 20, ст. 2817. 